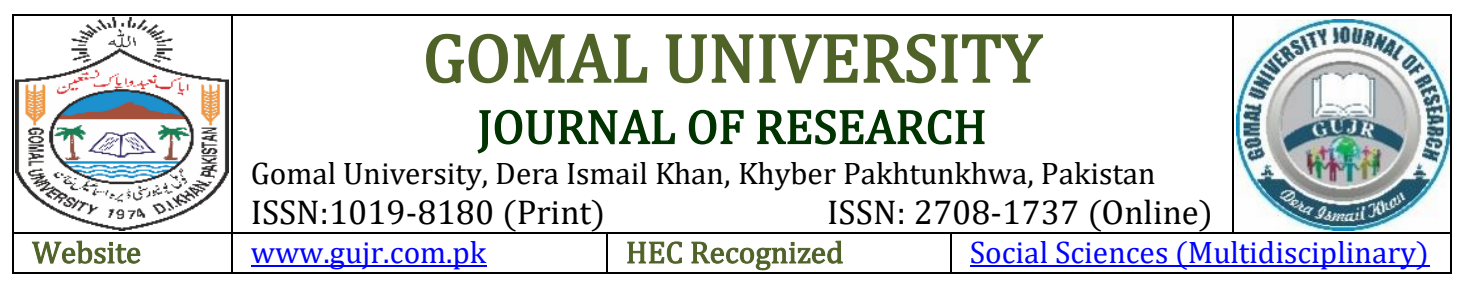

\title{
DeVeloping A Technology ACCEPTANCE Model For THE MOBILE BANKING ADOPTION IN PAKISTAN
}

\author{
Muhammad Ibrahim ${ }^{1}$, Muhammad Khalil Shahid ${ }^{2} \&$ Shuja Ahmed Syed ${ }^{3}$
}

${ }^{1}$ Center for Emerging Sciences Engineering \& Technology, Islamabad, KFUEIT, Pakistan

${ }^{2}$ Associate Professor, Center for Emerging Sciences Engineering \& Technology, Pakistan

${ }^{3}$ Professor, Center for Emerging Sciences Engineering \& Technology, Islamabad, Pakistan

\section{\begin{tabular}{l|l}
\hline ARTICLE INFO & ABSTRACT
\end{tabular}}

Keywords:

Telecom Sector, Ethics,

Risk, Innovation,

Customer Services

Article History:

Date of Submission:

01-09-2020

Date of Acceptance:

20-12-2020

Date of Publication:

31-12-2020
The Technology Acceptance Model (TAM) is a simplistic information system. The improved features of new technology strongly impact the consumer's use of it. The objective of the research was to develop TAM for online banking in Pakistan. This research was the primary research wherein data was collected from five hundred respondents which were students of universities of private and government sector (Islamabad/ Rawalpindi cities) through questionnaires. Correlation and regression tests were conducted via SPSS software; correlation analysis showed that a significant positive relationship exists without ethics among all the factors. In regression analysis value of $\mathrm{R} 2=0.621$ it indicates that every independent variable has $62 \%$ impact on dependent variable, model has capability to predict future results of research. The research result suggested that ethics and ethical values are the main hurdles in adoption of the mobile banking in Pakistan. The research findings will help the business managers and related organizations to reconstruct their business strategies in order to capture and retain the maximum potential customers.

\section{(c) 8 (9) 8}

2020 Gomal University Journal of Research

Corresponding Author

Muhammad Ibrahim: ibrahimkhanleghari@yahoo.com

https://doi.org/10.51380/gujr-36-02-06

\section{INTRODUCTION}

Mobile banking is ever perceived as the risky banking system, even the potentional consumers are even not willing to use mobile banking facilities, as millions of the dollars have been spent to launch this technology (Luarn, 2005). To handle daily banking affairs, lot of the advancement has been made in IT and Telecom technologies, the e-contracts between the countries has been exceed to 50\% (Pikkarainen, Pikkarainen, Karjaluoto \& Pahnila, 2004). Almost all the banks are using corresponding strategies due to evolutionary, regulatory requirements, competition and the customer preferences (Giannakoudi, 2010). According to Deloitte (2010) different published 
reports, only in USA, from 2008 to 2010 more than $60 \%$ sale of smart phones have been notice. In 2012, remaining 40\% consumers are expected to use smart phones (Deloitte, 2010). Actually, TAM is a data system; it defines however, users settle for new technology like as mobile banking. The TAM suggests that when innovative features are added, the consumer mind is influenced to adopt new system, specifically when the system is user friendly (Davis, 2011). According to PTA, in 2013 there were more than 122 million mobile consumers with annual tendensity of $68.8 \%$. The telecom services rates are very low in Pakistan as compared to other companies, therefore people from any income level group can use the media services without any insights (AFACT, 2009).

One of the most important factors is the MIS factor use for business purpose especially in mobile banking system (Bailey, 2018). The mobile banking is providing the facilities like as cost savings, swiftness, time liberty to attract customers. At present enlargement market diffusion is possible by the provision of different most advanced mobile banking facilities (Lee, Lee and Kim, 2007). The evaluation of mobile banking services is measured by smart Mobile phones which is also best source of improving banking services especially in unbanked or under banked areas (CGAP, 2006). The basic aim of this research was to know customer attraction towards mobile banking services. Recently in Pakistan wireless internet services made noticeable progress, so the mobile users' numbers are growing same the banks are focusing on to provide cheaper mobile banking services. Since this is really quite early stages of mobile banking, a massive gap needs to fill; it is therefore needed to conduct out research on factors like innovation, customer services, ethics and risk for mobile banking in Pakistan. As no research has been made on this topic with these factors. The human behavior is too complex to understand, this study initiatives to understand how much impact these factors have on consumers to adopt mobile banking in Pakistan. This research is further composed on literature review, methodology, result analysis, discussion, and recommendations.

\section{LITERATURE REVIEW}

According to a survey by ITU, more than 5billion people use mobile in world (ITU, 2004). The prediction is that mobile users will surpass users of desktop computer in 2015 (Ingram, 2010). The rapid advancement in technology has assured the widely availability of the mobile banking facility but few users operate it (Deloitte, 2010). At present due to wireless telecommunication mobile commerce is source of transaction either direct or indirect with value, these transactions may be shopping, banking, investing and services (Wu \& Wang, 2005). Mobile banking services in the USA have been increased from $14.9 \%$ to $40.5 \%$ from 2001 to 2007 (Graumann \& Koehne, 2003). Within the network coverage all the transactions are possible any time anywhere (Kreyer, Pousttchi \& Turowski, 2002). According to modern PTA stats, a huge number of cell phone users have reached more than 120. Five million by September 2012 (Attaa, 2012). Only 12\% of people use formal banking (Mahmood, 2011). According to (CGAP, 2011), the mobile banking providers have made huge investments in the digital payment infrastructure supply low-income mobile financial services. According to (Jahangiri, 2010) in Pakistan only 66\% out of 1.4 million mobile accounts are active. The traits of an innovation influence the consumer to use the product, these products are communicated over specific channels to members of society (Rogers \& Shoemaker, 2009).

The unique of associate innovation, influence the consumer to use product (Holak \& Lehmann, 2016). The innovation reduces the complexity and increases the adoption as well as the trust of 
customer on banking services that result in customer satisfaction (Puschel \& Hernandez, 2019). Due to innovation the auto operated machines and computer has taken the place of people and saved the salaries, expenses (Lewis, Palmer \& Moll, 2010) innovation are adopted if there will be greater likelihood (Cruz \& Laukkanen, 2010). The only device options might not be difficulty for bank consumers when considering mobile banking (Laukkanen, 2007). Mental speculations contend that singular conduct is unsurprising and affected by singular aim and demonstrated social goal to have noteworthy effect on innovation utilization. The point of banks is to draw in customers to receive their administrations as opposed to the expectation to embrace benefits, an examination has inspected the connection between social aim and genuine use (Venkatesh, 2000). In any case, just one work in surviving versatile financial examinations has brought this connection into the exploration structure which urges a need to look at the connection between social aim and the genuine conduct in the portable financial setting (Pedersen \& Thorbjornsen, 2002).

The record balance administration is one of most inspiring portable financial administrations, and is intended to assist clients with checking their record balance and latest exchanges right away whenever/anyplace (Attaa, 2012). The powerful utilization of the portable banking is the conceivable with the help of various gadgets accessible. The working arrangement of portable and equipment ought to give the banking applications. To save money on the cost's information transmission should be compressed. There may be a capacity to customize the showcase to bid to preferences of the various clients (Srite \& Karahann, 2006). On the off chance that the client needs detail data with respect to exchanges, there should the arrangement in the configuration to fulfill such needs. To include the incentive for the client cell phone must be able to give the opportune alarms and there should prudent utilization of such an application. The clients have capacity to utilize the broad highlights in electronic banking (Mahmood, 2011). Contributing the information is one of the main convenience containment vessels. By producing a click-frame in the most recent age of gadgets, the priority was on defeating this issue. Uses of banking would also like to address this issue because of simplification of customer use. Applications would want to precede use office in events, being disturbance of portable exchanges with no trading off the office.

This potential would expand their convenience considerably after disconnected. Applications ought to loan the simplicity of ease of use by giving them easy route keys to much of the time utilized exchanges. The clients must not have resort extensive contributing for availability of the information (CGAP, 2011). One of the large issues looked by the buyers is security before picking an innovation. Presently the banking is significant part of life and the cash misfortune could hamper the encounters with banks and other money related institutions (Wang, 2007). The cell phone for use of banking services is dependable, as it is concentrated by the a few specialists. Hazard is the mentality of client any item or then again administration, not the element of item or administration (Mattila, 2002). It is said that dangers change the perceptions of purchasers to utilize innovation. The solid encryption methods must be utilized by banks for security of the touchy and utilitarian information utilized in portable banking. It has been recommended by parcel of specialists that security isn't the primary obstacle embrace portable heating (Laforit and Li, 2005). A significant obstruction to scatter the portable financial use is its expense risk (Tarasewich \& Warkatin, 2002). For current portable financial which is related with cell phone that is purchase the hand set, get associated through a specialist organization causes an expense risk. 
Nah, Siau and sheng (2005) recognized monetary hazard as a negative effect on the conduct expectation to receive versatile banking. The investigation of 196 respondents in the Sultanate of Oman identified that significant expense hazard is critical to utilize versatile banking (Sadi and Noorudin, 2010). The exchanges of cash through versatile is still in its developing period yet the portable banking parts not yet worked for the 'extremely basic moral and good issues' if not investigated, it will fill in as untrustworthy direct of business (Boatright, 2009). Practically every association has exceptionally clear and composed moral codes, working techniques and industry standards. As an exploration by Badi and Badi (2009) characterized social impacts as how much the people see that significant others accept, he/she should utilize the innovation. An overview from major banks in Malaysia (Amin \& Anis, 2008) proposed that singular goal for utilizing portable banking was altogether influenced by individuals encompassing them. An exact confirmation by demonstrated that subject standards were notable impact. While found (Puschel, Mazzon \& Hernandez, 2010) that apparent pictures were noteworthy components for individuals' readiness to utilize versatile banking. In an examination by Trappey and Trappey (2001) established that the Chinese are utilized to carry cash, and have pretty much nothing trust in the conventional administration of fund when contrasted with other Asian customers, Chinese appear to be more customary and are less influenced by the new innovative and creative progressions.

\section{Figure 1}

Technology Acceptance Model (TAM) for Mobile Banking Adoption (Own Created)

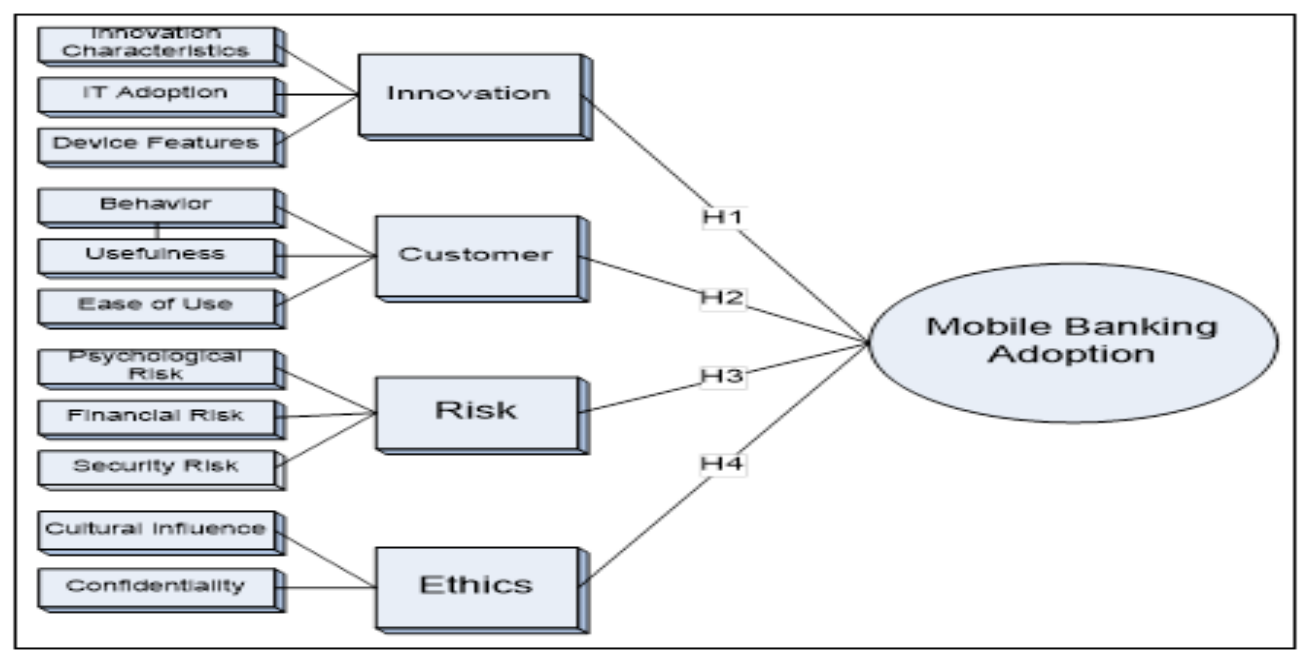

For this research model innovation, customer services, risk and ethics are independent variables while the mobile banking adoption is the dependent variable wherein the relationships have been examined in this study. After the deep study of the literature following hypo thesis are formulated:

H1: Innovation has positive relation with the mobile banking adoption. H2: Customer services have positive affect on mobile banking adoption. H3: Risk factor impacts negatively on the mobile banking adoption. H4: Ethics has negative impact on the mobile banking adoption. 


\section{RESEARCH METHODOLOGY}

The population of this analysis was the scholars of private and public sector universities of Islamabad/Rawalpindi. The sample was composed of 500 respondents, students of Bachelor to MS/MPHIL, the sampling technique used was a random sampling. As this research was primary research the source of data was the questionnaire which was developed after deep literature review, the range of Likert scale was from 1 to 5 , one shows strongly agree, two for the agree, the three for neutral, four was used for disagree and five was used to show strongly disagree. The Chronbach Alpha value was (o.80) that showed the high reliability of the questionnaire. The questionnaire was distributed to respondents for on spot filling in different sessions in order to get unbiased response. Few questionnaires were sent to respondents via email and reference of friends.

\section{Research Rate}

Out of 500 distributed questionnaires 472 were accurately filled as can been seen in table 1 , the research rate was $94 \%$. Some of questionnaires were missed that why they were not included in analysis.

Table 1

Research Rate

\begin{tabular}{ccc}
\hline Number of Questionnaire & Number of responses & Rate \\
\hline 500 & 472 & $94 \%$ \\
\hline
\end{tabular}

\section{Demographic Analysis}

For this research males were $62.6 \%$ with $37.4 \%$ females. The research was similar to (Boatright, 2009) which indicated that $65.6 \%$ were males and $34.4 \%$ were females as can be seen in table 2.

\section{Table 2}

Demographic Analysis

\begin{tabular}{ccc}
\hline Gender & Numbers & Percentage \\
\hline Male & 296 & 62.6 \\
Female & 176 & 37.4 \\
Age & & \\
$18-25$ & 199 & 42.1 \\
$25-30$ & 140 & 29.6 \\
$30-35$ & 133 & 28.3 \\
Qualification & & 30.3 \\
Bachelor & 143 & 27.3 \\
Master & 129 & 42.4 \\
MS/M.PHIL & 200 & \\
\hline
\end{tabular}

The demographic analysis is self-explanatory and no need to further explain the table. The range of the age was from 18-35 years with the qualification from the Bachelor to MS/MPHIL used in study. The demographics helps in providing the information about individualities in the context and nature of the individuals those whose responses have been further analyzed to explore the environment. 
Ibrahim et al... Developing A Technology Acceptance

\section{Correlation Analysis}

A study by (Cooper, and Schindler, 2011) proposed that correlation identifies association among the research factors. Therefore, to examine the association, current study also used correlation procedure.

Table 3

Correlations Analysis

\begin{tabular}{llcccc}
\hline & Innovation & $\begin{array}{c}\text { Customer } \\
\text { Services }\end{array}$ & Ethics & Risk \\
\hline Innovation & $\begin{array}{l}\text { Pearson Correlation } \\
\text { Sig. (2-tailed) }\end{array}$ & 1 & & & \\
Customer & Pearson Correlation & $0.312^{* *}$ & 1 & & \\
Services & Sig. (2-tailed) & .000 & & & \\
Ethics & Pearson Correlation & 0.139 & -0.37 & 1 & \\
& Sig. (2-tailed) & 0.069 & 0.634 & & \\
Risk & Pearson Correlation & $-.167^{*}$ & & $.366^{* *}$ & 1 \\
& Sig. (2-tailed) & 0.029 & 0.006 & 0.000 & \\
Mobile Banking & Pearson Correlation & $.337^{* *}$ & $0.413^{* *}$ & 0.015 & $-.159^{*}$ \\
Adoption & Sig. (2-tailed) & .000 & 0.000 & 0.844 & 0.038 \\
\hline
\end{tabular}

**. Correlation is significant at the 0.01 level (2-tailed).

*. Correlation is significant at the 0.05 level (2-tailed).

The research consisted of the four response variables, like ethics, innovation, client services and risk, because when mobile banking was the dependent variable. Correlation results indicate that variables like innovation and customer services have the positive, vital relationship with mobile banking, a negative, but significant, relationship between ethics and mobile banking adoption. An insignificant relationship has been found between ethics and mobile banking adoption. All the hypothesis is satisfied without ethics as insignificant relation was found in the correlation procedure.

\section{Regression Analysis}

The regression analysis test shows the relationship with the dependent variable of each freelance factor essentially it shows the suitability of the model. The results are discussed below.

\section{Table 4}

Regression Analysis of Innovation and Mobile Banking Adoption

\begin{tabular}{cccc}
\hline Model & Standardized Beta & T-Value & Significant \\
\hline Constant & & 3.233 & 0.001 \\
Innovation & 0.491 & 2.989 & 0.003 \\
\hline $\mathrm{R}=0.470$, R-Square $=$ 0.621 \& F-Value $=11.855$ & &
\end{tabular}

Table 5

Regression Analysis of Customer Services and Mobile Banking Adoption

\begin{tabular}{cccc}
\hline Model & Standardized Beta & T-Value & Significant \\
\hline Constant & & 3.233 & 0.001 \\
Customer Services & 0.531 & 4.550 & 0.000 \\
\hline
\end{tabular}


The value of standardized beta is 0.491 , it shows that the innovation has almost $50 \%$ impact on mobile banking adoption, and the t-value is greater than 2 which means that innovation has an effect on mobile banking adoption. Customer Services have 53\% impact on mobile banking adaption as the standardized beta value is 0.531 and the t-value is greater than 2 confirms strong effect.

\section{Table 6}

Regression Analysis of Ethics and Mobile Banking Adoption

\begin{tabular}{cccc}
\hline Model & Standardized Beta & T-Value & Significant \\
\hline Constant & & 3.233 & 0.001 \\
Ethics & 0.018 & 0.241 & 0.810 \\
\hline
\end{tabular}

$\mathrm{R}=0.470, \mathrm{R}-\mathrm{Square}=0.621 \& \mathrm{~F}-$ Value $=11.855$

Ethics has been observed low impact on mobile banking adoption as the value of standardized beta is 0.018 the $t$-value is the greater than 1, means that ethics do not affect the mobile banking adoption.

\section{Table 7}

Regression Analysis of Risk and Mobile Banking Adoption

\begin{tabular}{cccc}
\hline Model & Standardized Beta & T-Value & Significant \\
\hline Constant & & 3.233 & 0.001 \\
Risk & -0.059 & -0.776 & 0.439 \\
\hline
\end{tabular}

$\mathrm{R}=0.470, \mathrm{R}-$ Square $=0.621 \& \mathrm{~F}-$ Value $=11.855$

Risk has a negative effect as value of standardized beta is -0.059, it indicates that mobile banking adoption is not affected by Risk and also the $\mathrm{t}$-value -0.776 shows the negative relationship with criterion.

\section{CONCLUSION}

The research's main objective was to develop the model acquiescence with supporting factors reminiscent of innovation, client services, risk and ethics for adoption of internet banking in Pakistan. After extensive review of the literature proposed research model was developed. The study was based on certain assumptions those which were aimed to examine by using diverse statistical procedure in order to chase the objectives of the study related with the relationships of the research variables. The research results of innovation and customer services showed positive significant correlation, while the ethics and risks have negative correlation. In Pakistan nation, the Mobile banking is in growing, role of the telecom sector is major for this growth. Specifically, wireless communication operators must remove all the barriers to attract and retain these customers. Mobile banking organizations in order to win customer confidence must focus on conformation and accuracy of monitoring tools. The players of mobile banking should deeply monitor tools, accuracy and conformation to successfully achieve customer's confidence and must break all the political and global hurdles to attain the efficient and very well-regulated architecture. 


\section{Recommendations}

$\checkmark \quad$ Further, researchers and related organizations, specifically for the adoption of the mobile banking in Pakistan make sure that every country has its own banking, culture ethics and environment.

$\checkmark \quad$ The research areas may be enlarged about geographically and demographically, there is important role of restrictive authorities must play to reduce risk and unethical business way.

$\checkmark \quad$ There are lot of nations and countries of this universe, same the behavior and perception of people varies according to nation and country wise regarding the different issues and problems.

$\checkmark \quad$ In Asian countries mostly account based banking is preferred instead of mobile banking as compared France and USA, where people prefer mobile banking. So, for successful adoption of mobile banking, there is a dire need to understand local environment of each country.

\section{REFERENCES}

AFACT, (2009). Year Book. Pakistan Progress Report. E-Commerce Resource Center- Pakistan. State Bank of Pakistan. Banking Consumer's Education: Provision of Mobile Banking. 2006.

Amin, H., Hamid, M. R. A., Lada, S., \& Anis, Z. (2008). "The adoption of mobile banking in Malaysia: The case of Bank Islam Malaysia Berhad," International Journal of Business and Society, 9 (2), 43-53, 2008.

Attaa, A. (2012). Mobile Subscribers in Pakistan Reach 120.5 Million, http://propakistani. $\mathrm{pk} / 2012 / 12 / 05 /$ mobilesubscribers-in-pakistan-reach-120-5-million.

Badi, V., R., \& Badi, V., N., (2009). Business Ethics. Delhi, India: Vrinda Publications (P) Ltd. banking”, Journal of Services Marketing, 20 (3), 160-8.

Bailey, J. E., \& Pearson, S. W. (2018). Development of a tool for measuring and analyzing computer user satisfaction, Management Sciences, 29 (5), 530-545.

Boatright, R., J., (2009). Ethics and Conduct of Business, (5th ed). Delhi, India: Dorling Kindersley.

CGAP, (2006). Mobile Phone Banking and Low-Income Customers: Evidence from South Africa, http://www.globalproblems-globalsolutionsfiles.org.

CGAP. (2011). Case Study: United Bank Limited Supports Cash Transfer Payments. Washington, D.C.: CGAP. http://www.cgap.org/gm/document-1.9.50409/CGAP UBL case study Jan 2011.pdf.

Cooper, D. R., \& Schindler, P. (2011). Business Research Methods. (11th Ed.) Boston, McGrawHill.

Cruz, P. Neto, L., Munoz-Gallego, P., \& Laukkanen, T. (2010). "Mobile banking rollout in emerging markets: evidence from Brazil," International Journal of Bank Marketing, 28 (5), 342-371.

Davis, F. D. (2011). "Perceived usefulness, perceived ease of use, and user acceptance of information technology", MIS Quarterly, 13(3): 319-340.z

Deloitte, (2010). Introduction- mobile Banking at tipping point. fromhttp:/deloitte.com/asset/ DocomUnitedStata/Local\%20Asset/Documents/us_consulting_MobileBanking_010711. pdf. 
Khan et al... Is Social Support Moderates

Giannakoudi, S. (2010). Internet banking: The digital voyage of banking and money in cyberspace.

Graumann, S., \& Koehne, B. (2003). Monitoring Information Economy, 6 fact sheet 2003 NFO infratest on behalf of German ministry of economics. Munich, Germany.

Holak, S. L., \& Lehmann, D. R. (2016). Purchase Intentions and the Dimensions of Innovation: An Exploratory Model. Journal of Product Innovation Management, 7, 59-73.

Ingram, M. (2010). Mobile internet will soon overtake fixed internet. Mary-meker-mobile-willsoon-over-take-fixed-internet. International Journal of Mobile Communications, 3 (4), 325-38.

ITU, Reports. (2004). Information technology statistics. http:// itu.int/ITU-D/ict/ Statistics/at _ glance/Internet04.Pdf.

Jahangiri, T. (2010). An interview with saryGirn, Chief technology officer, Wesptac. Retsseved 30 January 2011. From http:///www.pst.net.au/whoswho.aspx?id=205 and op=mz.

Kreyer. N., Pousttchi, K., \& Turowski, K. (2002). Characteristics of mobile payment procedure. In proceeding of the ISMIS 20002. Workshop on M-Services (Maamar, Z., Mansoor, W., and Van Dan, Hcwel, W., J. Eds), France lyon.

Laforit, S., and Li, X. (2005). Commerce attitude towards online and mobile banking in china, International journal of bank marketing, 23, 5, 362-380.

Laukkanen, T. (2007) "Internet vs. mobile banking: comparing customer value perceptions," Business Process Management Journal, Vol. 13, No. 6: 788-797.

Lee, K. S., Lee, H. S., \& Kim, S. Y. (2007). Factors influencing the adoption behavior of mobile banking: A South Korean perspective. Journal of Internet Banking and Commerce, 12(2).

Lewis, N., Palmer, A., \& Moll, A. (2010). "Predicting young consumers'take up of mobile banking services," International Journal of Bank Marketing, 28 (5), 410-432.

Luarn, P. (2005). Towards an understanding the behavioral intention to use mobile banking. Computers in Human Behavior, 21, 873-891.

Mahmood, M. (2011). Branchless Banking in Pakistan-Opportunistic View, http:// propakistani.pk/2011/12/o7/branchless-banking-in-pakistan-opportunistic-view.

Mattila, M. (2002). Factor effecting the adoption of mobile banking services. Journal of Internet banking and commerce. Retrieved From http://www.arraydev.com/commerce/jibc/o306 -04.htm.

Nah, F., Siau, K., \& Sheng, H. (2005). The value of mobile application: a study on a public utility company. Communications of the ACM, 48, 2, 85-90.

Pedersen, P. E., Methlie, L. B., \& Thorbjornsen, H. (2002). Understanding mobile commerce end-user adoption: a triangular perspective and suggestion for an exploratory services evaluation from work. Proceeding of 35 Hawaii International Conferences on system science.

Pikkarainen, T., Pikkarainen, K., Karjaluoto, H., \& Pahnila, S. (2004). Consumer acceptance of online banking: an extension of technology acceptance model. Internet Research, 14(3), 224-235.

Puschel, J. M. J., \& Hernandez, J. (2019), "Mobile banking: proposition of an integrated adoption intention framework," International Journal of Bank Marketing, 28 (5), 389409.

Puschel, J., J. A. Mazzon, \& Hernandez, J. M. C. (2010). Mobile banking: Proposition of an integrated adoption intention framework. International Journal of Bank Marketing, 28, (5), 389-409, 2010.

Gomal University Journal of Research, Volume 36, Issue 2, DECEMBER, 2020 
Rogers, K., \& Shoemaker, P. (2009). Communication of Innovations,Product Management and Marketing Tools, C) Bill Swinyard 1999,Crossing the Chasm: 2.0, [Online]. vailable: http://marketing.byu.edu/download/chasm.ppt

Sadi, A. H. M. Azad, I. S., \& Noorudin, M. F. (2010). "The prospects and user perceptions of mbanking in the Sultanate of Omen," Journal of Internet Banking and Commerce, 15 (2): 111, 2010.

Srite, M., \& Karahann, E. (2006). The role of Espoused National cultural values in technology acceptance. MIS Quarterly, 30, 3, 679-704.

Tarasewich, P., Nicleerson, R. C., \& Warkatin, M. (2002). Issues in mobile e-commerce. Communication of the Association of Information System, 8, 41-64.

Trappey, C. V., \& Trappey, A. J. C. (2001). Electronic commerce in Greater China. Industrial Management and Data Systems, 101 (5), 201-220.

Venkatesh, V. (2000), "Determinant of perceived ease of use: integrating control, intrinsic motivation and emotion in to TAM", Information System Research, 11 (4), 342-65.

Wang X. L. (2007). The Impacts of Chinese Cultural Factors on Users' Online Trust in ECommerce.

Wu, J.-H. \& Wang, S.-C. (2005) "What drives mobile commerce? An empirical evaluation of the revised technology acceptance model”, Information and Management, 42 (5), 719-29. 